\title{
Prinsip-Prinsip Praktik Bisnis dalam Islam bagi Pelaku Usaha Muslim
}

\author{
Abdurrahman Alfaqiih \\ Fakultas Hukum Universitas Islam Indonesia \\ Jln. Tamansiswa No. 158 Yogyakarta \\ abdurrahmanalfaqiih@gmail.com
}

Received: 22 Maret 2017; Accepted: 1 Agustus 2017; Published: 28 Februari 2018

DOI: 10.20885/iustum.vol24.iss3.art6

\begin{abstract}
Islam affirms the divine values of nobility as a foundation in any business practices for Muslim business actors. However, there are a lot of businessmen who tend to perform business practices that cause disadvantages to others and to the environment. This study discussed two problems. First, what are the basic principles of Islamic business practices? Second, what is the basic framework for such Islamic business principles? This study reviewed business principles according to Islamic perspectives in a descriptive qualitative manner by using a normative approach and referring to secondary data sources. This study concluded that, firstly, moral values such as fairness, honesty, trustworthiness, professionalism, transparency, liability, far from being haram are the basic principles in Islamic business practices for Muslim business actors. Second, these principles are sourced from the Qur'an and Sunnah, arranged within the framework of Beliefs, Worship and Morality.
\end{abstract}

Keywords: Principles; Business Practices; Islam; Business Actors; Muslim

\section{Abstrak}

Islam menegaskan nilai-nilai keluhuran ilahiah sebagai landasan dalam praktek bisnis bagi pelaku bisnis muslim. Namun demikian, tidak sedikit pelaku bisnis yang cenderung mempraktikkan bisnis yang merugikan bagi orang lain bahkan terhadap lingkungan. Penelitian ini mengangkat dua permasalahan. Pertama, bagaimana prinsip dasar praktik bisnis dalam Islam? Kedua, apakah kerangka dasar prinsip tersebut dalam Islam? Penelitian ini mengulas prinsip dalam praktik bisnis ditinjau dari perspektif Islam secara deskriptif kualitatif dengan pendekatan normatif dan merujuk pada sumber data sekunder. Penelitian ini menyimpulkan, pertama, nilai-nilai moral seperti keadilan, kejujuran, amanah, profesionalisme, transparan, dapat dipercaya, jauh dari hal yang haram dan kezaliman merupakan prinsip dasar dalam praktik bisnis bagi pelaku usaha muslim. Kedua, prinsip-prinsip tersebut bersumber pada Al-Qur'an dan Sunnah yang dibingkai dalam kerangka Akidah, Ibadah dan Akhlak.

Kata-kata Kunci: Prinsip; Praktik Bisnis; Islam; Pelaku Usaha; Muslim 


\section{Pendahuluan}

Bisnis $^{1}$ merupakan instrumen vital dalam kehidupan masyarakat. Hal ini dapat dilihat salah contohnya dari peranannya terhadap pembangunan ekonomi suatu negara. Alma Buchari mengatakan bahwa peningkatan kekuatan ekonomi bangsa salah satunya ditopang dengan eksistensi bisnis yang masif dengan didukung penciptaan lapangan kerja baru. ${ }^{2}$ Hal ini bukanlah sesuatu yang baru, sebab sejak empat belas abad yang lalu praktik bisnis telah tumbuh pesat. ${ }^{3}$ Sebagai contohnya adalah bahwa kegiatan bisnis merupakan pekerjaan duniawi utama yang dilakukan oleh Rasulullah Muhammad SAW.

Aktifitas bisnis bagi umat muslim bukanlah suatu hal yang baru. Secara normatif, Al-Qur'an memuat kata bisnis dengan sebutan al-tijarah, yang bermakna niaga atau dagang. ${ }^{4}$ Praktik bisnis telah berlangsung sejak 14 abad silam. Namun dewasa ini, problem bisnis yang dihadapi oleh kalangan muslim menjadi begitu kompleks. Walaupun aktif berkecimpung dalam praktik bisnis, tetapi ketidakpastian bahwa praktik bisnis tersebut sudah benar menurut ajaran Islam atau belum selalu membayangi benak pikiran umat muslim. ${ }^{5}$

Dewasa ini, di era globalisasi, praktik bisnis menjadi semakin terbuka dan sarat akan persaingan. Dalam kondisi demikian, pemerintah di satu sisi dituntut tidak melakukan intervensi, namun di sisi lain pemerintah juga punya tanggung jawab menjaga iklim bisnis yang kondusif dengan cara mengatur persaingan tersebut secara adil yang mana hal ini dapat dipandang sebagai salah satu bentuk campur tangan pemerintah. ${ }^{6}$

Meskipun pemerintah hadir di tengah praktik bisnis, perannya hanya sebagai "wasit". Tidak heran bila kemudian masih dijumpai praktik bisnis yang disinyalir menyimpang. Contohnya, bisnis atau perusahaan besar yang cenderung mengabaikan tanggung jawab sosial dalam hal dampak lingkungan dan dampak

1 Bisnis dapat dipahami sebagai segala aktifitas yang dilakukan secara terus menerus dengan orientasi mendapatkan keuntungan. Menurut ar-Raghib al-Asfahani dalam al-mufradat fi gharib al Qur'an, at-Tijarah bermakna pengelolaan harta benda untuk mencari keuntungan. Lihat Fitri Amalia, "Etika Bisnis Islam: Konsep Dan Implementasi Pada Pelaku Usaha Kecil”, Al-Iqtishad, Vol. VI, No. 1, 2014, hlm. 135.

2 Alma Buchari, Manajemen Pemasaran dan Pemasaran Jasa, Cet. Ke-8, Alfabeta, Bandung, 2009, hlm. 94.

${ }^{3}$ Mustaq Ahmad, Etika Bisnis Dalam Islam, Pustaka Al-Kautsar, Jakarta, 2001, hlm. 1.

${ }^{4}$ Fitri Amalia, Loc. Cit.

${ }^{5}$ Ibid

${ }^{6}$ Ibid 
penggunaan produk oleh konsumen. Persekongkolan antar pelaku bisnis bukan juga merupakan isapan jempol, bahkan tidak sedikit juga dari mereka yang bersepakat dalam kejahatan dengan penguasa guna mendapatkan sokongan dana dan kemudahan ijin dan perlindungan. Sehingga bisnis yang demikian cenderung berkembang cepat dan terkesan tidak fair karena mempunyai jalan untuk memonopoli. ${ }^{7}$

Realita yang dijumpai adalah tidak jauh berbeda dari asumsi di atas. Di tengah tekanan ekonomi yang semakin sulit, tidak sedikit pelaku bisnis yang semata-mata berorientasi mencari keuntungan dan mengesampingkan nilai prinsipil yang luhur sebagai makhluk sosial. Oleh karenanya, cara apapun digunakan dengan mengorbankan aspek moralitas karena dianggap menghalangi kesuksesan dalam bisnis, dan disinyalir membatasi keleluasaan pergerakan bisnis. ${ }^{8}$

Bukan suatu hal yang mengagetkan apabila di Indonesia sering dijumpai pemberitaan tentang praktik bisnis yang menyimpang. Praktik bisnis tersebut bersinggungan langsung dengan hajat hidup masyarakat banyak. Sebagai contoh, kecurangan dalam praktik bisnis makanan. Mulai dari pemalsuan saus yang diduga bahan pembuataannya menggunakan bahan kimia yang berbahaya untuk dikonsumsi, ${ }^{9}$ ikan, cumi-cumi, udang, kerang dan sejeninya yang diduga mengandung bahan klorin dan formalin dijual bebas di pasar tradisional, ${ }^{10}$ hingga sari kelapa atau dikenal dengan sebutan nata de coco disinyalir mengandung pemutih dan boraks. ${ }^{11}$ Belum lagi terungkapnya peredaran makanan daluwarsa yang masih dijual di pasaran. ${ }^{12}$

Terlepas dari motif pemberitaan tersebut, uraian pemberitaan mengenai peredaran bisnis makanan yang membahayakan telah mengusik benak pikiran masyarakat. Ditambah lagi bahwa pemberitaan tersebut didukung dengan proses

\footnotetext{
${ }^{7}$ R. Lukman Fauroni, Etika Bisnis Dalam Al-Qur'an, Pustaka Pesantren, Yogyakarta, 2006, hlm. v-vi.

${ }^{8}$ Ibid., hlm. 1.

9 Anonim, "Digerebek, Pabrik Saus di Bandung Ini Pakai Pewarna Tekstil Bukan Cabai dan Tomat" dalam https:// news.detik.com/jawabarat/2814332/digerebek-pabrik-saus-di-bandung-ini-pakai-pewarna-tekstil-bukancabai-dan-tomat, diakses pada tanggal 10 Juni 2016.

${ }^{10}$ Fadhil Al Birra, "Waspada! Ikan Berformalin Banyak Beredar, Begini Cara Membedakannya" dalam https://www.jawapos.com/read/2017/06/09/136193/waspada-ikan-berformalin-banyak-beredar-begini-caramembedakannya, diakses pada tanggal 10 Juni 2017.

11 Baca http://food.detik.com/read/2012/08/01/154109/1980557/297/waspadai-nata-de-cocomengandung-pemutih-dan-boraks, diakses pada tanggal 12 Juli 2016.

12 Ibid
} 
investiagasi yang direkam melalui video yang tentunya membuat masyarakat awam yang melihat tayangan tersebut akan lebih meyakininya. Di balik itu semua, hal yang menjadi penting sebenarnya adalah kecenderungan praktik bisnis curang dan membahayakan konsumen bukanlah hal yang bersifat rahasia. Memang benar dalam konteks ini, pemerintah juga turut andil yaitu mengawasi melalui lembaga pengawas makanan, namun hal itu memiliki keterbatasan.

Fenomena tersebut di atas bisa jadi dipicu oleh krisis moral dari para pelaku bisnis yang hanya ingin mencari keuntungan sebesar-besarnya dengan menggunakan modal sekecil mungkin. Menjadi sangat ironis bila pelaku bisnis tersebut ternyata banyak dari kalangan umat muslim. Pengungkapan masalah prinsip dan nilai etis dalam berbisnis menjadi penting untuk dilakukan dalam rangka menyelaraskan nilai-nilai etis dengan praktik bisnis yang pada era modern ini semakin diabaikan. Dalam rangka upaya memperjelas hal-hal tersebut maka perlindungan bagi para pelaku bisnis dan juga konsumen semakin nampak jelas. Pelaku bisnis setidaknya akan terlindungi oleh prinsip-prinsip tersebut dari praktik persaingan yang tidak sehat, sementara konsumen menjadi tidak waswas akan acaman produk yang membahayakan yang didapat dari pelaku bisnis yang mendasarkan prinsip-prinsip tersebut.

\section{Rumusan Masalah}

Berdasarkan uraian di atas, terdapat dua permasalahan dalam penelitian ini yaitu: pertama, bagaimana prinsip dasar praktik bisnis dalam Islam? Kedua, apakah kerangka dasar prinsip bisnis dalam Islam?

\section{Tujuan Penelitian}

Penelitian ini bertujuan untuk mengidentifikasi dua hal, pertama, prinsip praktik bisnis dalam Islam. Kedua, nilai-nilai etis yang mesti dirujuk dalam melakukan bisnis bagi kalangan muslim.

\section{Metode Penelitian}

Penelitian ini merupakan penelitian hukum normatif dengan pendekatan konseptual, yaitu pendekatan yang merujuk pada konsep dasar ajaran Islam. Sumber data yang digunakan dalam penelitian ini adalah sumber data sekunder 
yang terdiri dari bahan hukum primer, seperti Al-Qur'an dan Hadist, bahan hukum sekunder yang meliputi buku, artikel jurnal yang terkait dengan permasalahan dalam penelitian ini, dan bahan hukum tersier seperti kamus bahasa. Hasil data yang telah diperoleh dianalisis secara desktriptif kualitaif, yaitu mengklarifikasi fenomena praktek bisnis dengan jalan mendeskripsikan konsep dasar ajaran agama Islam yang relevan.

\section{Hasil Penelitian dan Pembahasan}

\section{Prinsip dasar ajaran Islam}

Pada dasarnya ajaran Islam memuat tiga pilar substansial yaitu akidah, ibadah dan akhlaq. Islam adalah agama fitrah, yang diturunkan Allah sebagai agama petunjuk dan pengarah bagi manusia untuk menjalankan agama yang benar. Secara fitrah juga manusia dilahirkan dengan pembawaan karakter dan keyakinan yang bersifat monoteisme atau mengesakan Allah, yang kemudian berimbas pada bentuk peribadatan atau penghambaan kepada Nya, lalu berujung pada terbentuknya akhlaqul karimah yang dapat membawa kedamaian dan kasih sayang bagi alam semesta atau yang biasa dikenal dengan sebutan rahmatan lil'alamin. $^{13}$

\section{Aqidah}

Hal vital dan fundamental dalam ajaran Islam adalah akidah. Akidah dianggap sebagai poros utama atau tiang penyanggah dari ajaran Islam. Status amal perbuatan manusia di hadapan Allah tergantung pada akidahnya. ${ }^{14}$ Bila menilik arti kata akidah berdasarkan kamus Bahasa Arab al munjid, dapat diketahui bahwa asal kata akidah mencakup al-'aqdu yang artinya ikatan; at-tautsiiqu yang artinya kepercayaan atau keyakinan yang kuat; al-ihkaamu yang berarti menetapkan (mengokohkan) dan ar-robtu biquw-wah yang artinya mengikat dengan kuat. 15

Apabila meninjau arti secara istilah, akidah dapat dimaknai sebagai pembenaran suatu hal atau urusan dengan hati dan penerimaan terhadap sesuatu hal atau urusan tersebut dengan puas, serta peneguhan dan penanamannya

\footnotetext{
13 Tim DPPAI, Pilar Substansial Islam, Cetakan Ketiga, DPPAI UII, Yogyakarta, 2016, hlm. 10.

${ }^{14}$ Nasiruddin Razak, Dienul Islam, PT al-Ma'arif, Bandung, 1971, hlm. 120

15 Louis Ma'luf, Al Munjid, Dar al Masyrid, Beirut, 1997, hlm. 519
} 
dengan kuat tanpa goyah karena syubhat. ${ }^{16}$ Akidah merupakan suatu bentuk keimanan yang muncul dari sumber yang intangible dan abstrak namun memiliki daya paksa terhadap manusia untuk menggapai sesuatu tanpa dalil. ${ }^{17}$ Cerminan definisi tersebut termanifestasikan dalam Qur'an Surat (QS) al-Baqarah ayat 177 yang artinya: "Bukanlah menghadapkan wajahmu kearah timur dan ke barat itu suatu kebaktian, akan tetapi sesungguhnya kebaktian itu ialah kebaktian orang yang beriman kepada Allah, hari kemudian malaikat-malaikat, kitab-kitab, nabinabi..."

Akidah dalam konsep agama, dianggap sebagai representasi dari empat unsur yang terkandung dalam agama sebagaimana yang diuraikan oleh AlMunawar sebagai berikut:18 Pertama, adanya keyakinan atau kepercayaan terhadap adanya tuhan atau kekuatan ghaib tempat berlindung dan memohon pertolongan; Kedua, adanya hubungan yang sebaik-baiknya dengan tuhan guna mencapai kesejahteraan hidup di dunia dan akhirat; Ketiga, adanya rasa mencintai dan melaksanakan perintah tuhan, serta menjauhi larangannya dengan jalan beribadah setulusnya dan meninggalkan segala hal yang dilarangnya; Keempat, adanya keyakinan atas hal-hal yang dianggap suci dan sakral seperti kitab suci, tempat ibadah dan sebagainya.

Dari uraian di atas, dapat dikatakan bahwa akidah merupakan bentuk peribadatan (penghambaan dan penyerahan diri) manusia yang paling utama, sebagaimana bunyi QS al-An'am ayat 82 yang artinya: “Orang-orang yang beriman dan tidak mencampuradukan iman mereka dengan kedzaliman (syirik), mereka itulah orang-orang yang mendapat keamanan dan mereka itu adalah orang-orang yang mendapat petunjuk". Dengan demikian, bila seorang hamba telah menisbatkan dirinya untuk tunduk dan hanya mengakui Allah sebagai satusatunya tuhan bagi dirinya yang patut disembah, maka dia juga harus mengakui dan mengikuti segala hal yang dimiliki, diperintah dan diciptakan Allah di muka bumi ini. Allah menciptakan alam semesta dan juga manusia untuk menghuninya

${ }^{16}$ Hasbi Ash Shiddieqy, Sejarah dan Pengantar Ilmu Taubid/Kalam, Bulan Bintang, Jakarta, 1973, hlm. 187

${ }^{17}$ Hasbi Ash Shiddieqy, Ilmu Kalam, Bulan Bintang, Jakarta, 1986, hlm. 43

18 Said Agil Husin Al-Munawar, Aktualisasi Nilai-Nilai Qur'ani Dalam Sistem Pendidikan Islam, Ciputat Press, Jakarta, 2003, hlm. 29 
dan memanfaatkannya sebagaimana Allah telah menyatakan dalam Qur'an Surat Al-An'am ayat 1 yang artinya: "Segala puji bagi Allah Yang telah menciptakan langit dan bumi, dan mengadakan gelap dan terang, namun orang-orang yang kafir mempersekutukan (sesuatu) dengan Rabb-mereka"; dan ayat 73 yang artinya: "Dan Dia-lah yang menciptakan langit dan bumi dengan benar. Dan benarlah perkataan-Nya di waktu Dia mengatakan: 'Jadilah, lalu jadilah', dan di tanganNya-lah segala kekuasaan di waktu sangkakala ditiup. Dia mengetahui yang gaib dan yang tampak. Dan Dialah Yang Maha Bijaksana, lagi Maha Mengetahui."

Allah juga telah menyediakan segala sumber daya alam di muka bumi ini untuk dapat dimanfaatkan oleh manusia dengan kekuatan yang diberikan Nya. ${ }^{19}$ Dengan ketersediaan yang sedemikian rupa, Allah menjadikan manusia sebagai khalifah (pemimpin) di muka bumi dengan label ciptaan dan posisi yang sempurna dibandingkan makhluk ciptaan Allah lainnya.. ${ }^{20}$ Manusia diciptakan dengan kemampuan dan kebebasan untuk memilih jalan yang benar dan yang buruk, mampu membedakan kedua hal tersebut. ${ }^{21}$ Oleh karenanya Allah memberikan amanah dan tanggung jawab yang besar kepada manusia untuk merealisasikan kehendak Nya dalam bingkai moral. Inilah kemudian yang dianggap sebagai raison d'etre tugas utama manusia diciptakan di muka bumi ini. ${ }^{22}$

\section{Ibadah}

Prinsip dasar ajaran Islam yang kedua adalah ibadah. Jika dicermati kata ibadah dapat dimaknai dengan makna kepatuhan, tunduk dan budak. ${ }^{23}$ Selain itu, makna dari kata ibadah juga dapat dipahami sebagai kelemahan dan kerendahan

${ }^{19}$ Qur'an Surat Ibrahim ayat 32-33 yang artinya: “Allah-lah yang telah menciptakan langit dan bumi dan menurunkan air hujan dari langit, kemudian Dia mengeluarkan dengan air hujan itu berbagai buah-buahan menjadi rejeki untukmu; dan Dia telah menundukkan bahtera bagimu, supaya bahtera itu berlayar di lautan dengan kehendak-Nya, dan Dia telah menundukkan (pula) bagimu sungai-sungai"(32) "dan Dia telah menundukkan (pula) bagimu matahari dan bulan yang terus-menerus beredar (dalam orbitnya); dan telah menundukkan bagimu malam dan siang"(33)

${ }^{20}$ Qur'an Surat Al-Baqarah ayat 30 yang artinya: “Ingatlah, ketika Rabb-mu berfirman kepada para Malaikat: 'Sesungguhnya Aku hendak menjadikan seorang khalifah di muka bumi'. Mereka berkata: 'Mengapa Engkau hendak menjadikan (khalifah) di bumi itu, orang yang akan membuat kerusakan padanya dan menumpahkan darah, padahal kami senantiasa bertasbih, dengan memuji Engkau, dan mensucikan Engkau'. Rabb berfirman: 'Sesungguhnya, Aku mengetahui, apa yang tidak kamu ketahui'".

${ }^{21}$ Qur'an Surat Al-Insaan ayat 3 yang artinya: “Sesungguhnya Kami telah menunjukinya jalan yang lurus; ada yang bersyukur dan ada pula yang kafir". Qur'an Surat Al-Balad ayat 10 yang artinya: "Dan Kami telah menunjukkan kepadanya, dua jalan".

22 Mustaq Ahmad, Op. Cit., hlm. 26

23 Amin Syukur, Pengantar Studi Islam, CV Bima Sakti, Semarang, 2003, hlm. 80 
di satu sisi, dan sebagai kekerasan dan kekasaran di sisi lain. ${ }^{24}$ Sedangkan secara istilah, Quraish Shihab memberikan batasan kata ibadah sebagai berikut:25

Ibadah adalah suatu bentuk ketundukan dan ketaatan yang mencapai puncaknya sebagai dampak dari rasa pengagungan yang bersemai dalam lubuk hati seseorang terhadap siapa yang kepadanya ia tunduk. Rasa itu lahir akibat adanya keyakinan dalam diri yang beribadah bahwa obyek yang kepadanya ditujukan ibadah itu memiliki kekuasaan yang tidak dapat terjangkau hakikatnya.

Segala sesuatu yang mencakup semua hal yang diridhoi dan dicintai oleh Allah SWT, yang meliputi ucapan ataupun amalan, secara terang-terangan atau secara sembunyi-sembunyi, merupakan ibadah menurut Ibnu Taimiyah. ${ }^{26}$ Dengan demikian dapat dipahami bahwa ibadah adalah bentuk penyerahan diri yang mencakup hati, perkataan dan perbuatan yang sifatnya komunal dan total kepada Yang Maha Pencipta. Hal ini bertujuan untuk meningkatkan dan menguatkan nilai-nilai ketauhidan dalam jiwanya. Kuatnya fondasi tauhid seseorang tidak lain dipengaruhi secara signifikan oleh intensitas ibadahnya, sehingga jiwa raga seseorang akan jauh dari nilai-nilai ketauhidan bila jarang beribadah. ${ }^{27} \mathrm{Hal}$ ini diperkuat dengan dalil Qur'an Surat al-Dzariyat ayat 56, yang artinya: "Dan aku tidak menciptakan jin dan manusia melainkan agar mereka beribadah kepada Ku".

Ibadah dapat dikategorikan menjadi ibadah mahdloh dan ibadah ghairu mahdloh. Kategori pertama dipahami sebagai ibadah yang telah Allah tentukan tata cara dan detail pelaksanaannya, seperti sholat, puasa, haji, wudhu, tayyamum dan umroh. Ibadah ini disebut juga ibadah khusus. Sedangkan kategori kedua cenderung diidentikkan dengan ibadah umum, karena semua amalan yang Allah ridhoi tergolong ibadah ghairu mahdloh, contohnya tolong menolong, menjalankan bisnis, belajar, dzikir, dan bekerja. ${ }^{28}$ Dengan demikian, ibadah merupakan output dari penerapan akidah. Semakin kuat akidah seorang muslim seharusnya semakin tinggi level pelaksanaan ibadahnya kepada Allah. Hal ini didasari dengan Qur'an

${ }^{24}$ Lihat Abu Husain Ahmad Ibn Faris ibn Zakariya, t.th, Mu'jam Maqa yis al-Lugah, Juz IV, Daar al-Fikr, Beirut, hlm. 205.

${ }_{25}$ M. Quraish Shihab, Fatwa-fatwa Seputar Ibadah Mabdah, Cet. I, Mizan, Bandung, 1999, hlm, 21.

${ }^{26}$ Ghoffar Ismail, dkk, Panduan Kuliah Intensif al-Islam (KIAI) UMY, Edisi Revisi, LPPI UMY dan UNIRES Pres, Yogyakarta, 2014, hlm. 15.

27 Abu al-Fida Muhammad bin Kasir, t.th, Tafsir al-Qur'an al-Karim, Juz I, Toha Putra, Semarang, tt, hlm 6-7.

${ }_{28}$ Muhammad Alim, Pendidikan Agama Islam, PT. Remaja Rosdakarya, Bandung, 2006, hlm 144-147. 
Surat al-Dzariyat ayat 56 yang dijelaskan di atas dan juga ditambah dengan makna Qur'an Surat al-Fatihah ayat 5 yang artinya: "hanya kepadaMu kami menyembah dan hanya kepadaMu kami memohon pertolongan". Pada hakekatnya hidupnya seorang muslim hanyalah untuk ibadah kepada Allah.

\section{Akhlaq}

Akhlak merupakan cerminan jiwa dan sifat reflektif yang menggambarkan pola kehidupan seseorang dalam melahirkan perbuatan atau perilaku zero value yang konstan dan independen. Refleksi perlaku ini merupakan pengejawantahan Iman, Islam dan Ihsan. ${ }^{29} \mathrm{Hal}$ ini sejalan dengan definisi akhlak yang disuguhkan oleh al-Ghazali, yaitu:30 "sifat yang tertanam dalam jiwa yang mendorong lahirnya perbuatan dengan mudah dan ringan, tanpa pertimbangan dan pemikiran yang mendalam".

Definisi akhlaq yang tak jauh berbeda datang dari Ibnu Miskawaih yang berpendapat bahwa akhlaq sebagai suatu kondisi yang menyatu pada manusia untuk berbuat dengan mudah tanpa proses pertimbangan akal pikiran. ${ }^{31}$ AlGhazali juga berpandangan bahwa manusia terdiri dari dua elemen, yaitu khalq yang identik dengan kebaikan yang nampak secara fisik; dan khuluq atau akhlaq yang berupa kebaikan spiritual atau bentuk kebaikan batiniah. Oleh karenanya, akhlaq akan berakar dari hati yang kemudian termanifestasikan dalam perilaku seseorang. ${ }^{32}$ Sementara itu, al-Maududi menggambarkan buah dari akhlak dengan perumpamaan sebagai berikut: 33

“orang taatnya benar pada lahirnya tetapi tidak benar pada batinnya, seperti satu tubuh yang elok paras mukanya, tetapi sudah ditinggalkan oleh ruhnya. Dan orang yang amalnya seluruhnya sempurna pada batinnya, taatnya tidak benar menurut cara yang dikehendaki pada lahirnya, seperti orang yang saleh yang buruk mukanya, buta kedua matanya dan pincang kedua kakinya".

Al-Ghazali menambahkan bahwa pada hakekatnya manusia adalah sama, yang berbeda hanya penampakan fisik saja. Sehingga, ketika manusia berada

${ }^{29}$ Sidik Tono, dkk, Ibadah dan Akblak dalam Islam, Cet. Ke-3, Ed. Aunur Rohim Faqih \& Amir Mu'allim, UII Press, Yogyakarta, 2009, hlm. 83.

${ }^{30}$ Ibid., hlm. 82.

${ }^{31}$ M. Yatimin Abdullah, Studi Akblaq dalam Perspektif Al-Qur'an, Amzah, Jakarta, 2007, hlm. 4.

32 Adibah Binti Abdul Rahim, "Understanding Islamic Ethics and Its Significance on the Character Building", International Journal of Social Science and Humanity, Vol. 3 No. 6, 2013, hlm. 508.

33 Abul A'la al-Maududi, Prinsip-prinsip Islam, Cet. Ke-2, Penterjemah, Abdullah Suhaili, PT Alma'arif, Bandung, 1983, hlm. 128. 
dalam kurun waktu tertentu maka ia akan berbeda dari masa waktu tertentu lainnya. ${ }^{34}$ Secara rohani, manusia terstruktur dari empat unsur, yaitu qalb, ruh, nafs dan akal. ${ }^{35}$ Di balik itu, manusia juga berpotensi memiliki empat macam tabi'at, yaitu kekasaran, kesetanan, kebinatangan dan kesucian. ${ }^{36}$

Berdasarkan penjelasan di atas, dapat dipahami bahwa spontanitas sebuah tindakan yang bersumber dari hati manusia yang fitri dapat dianggap sebagai akhlak. Kecenderungan tindakan yang berakar pada hati dan ruh adalah membentuk potensi orang yang suci, sebaliknya bila akal dan nafsu yang dominan, maka cenderung menampakkan kekasaran, kesesatan dan kebinatangan pada sifat manusia tersebut. Oleh karenanya, akhlak menjadi buah atau hasil dari penerapan akidah dan ibadah yang benar.

Dalam ajaran Islam, akhlak tentunya berpedoman pada al-Qur' an dan Hadits. Sebagai contoh Qur'an Surat al-Qalam ayat 4 yang artinya: "Dan sesungguhnya, kamu (Muhammad) benar-benar berbudi pekerti yang agung". Hal ini diperkuat dengan hadist nabi yang diriwayatkan oleh Muslim, yaitu ketika Aisah istri rosul ditanya tentang karakter beliau, Aisah menjawab bahwa karakter perilaku kepribadian Nabi Muhammad merupakan cerminan dari Al-Quran. Artinya bahwa bangunan konsep akhlak yang hakiki terdapat pada al-Qur'an dan Hadits. Sebagai contoh, pondasi akhlak yang pertama adalah beriman kepada Allah, ikhlas, berkomunikasi yang baik dan selalu berbuat kebajikan, sebagaimana yang tertuang dalam Qur'an Surat an-Nisa ayat 125 dan Qur'an Surat Fush Shilat ayat 33. ${ }^{37}$ Masih banyak lagi bangunan konsep akhlak yang terdapat dalam al-Qur'an seperti dalam Qur'an Surat an-Nisa' ayat 36, al-Ahzab ayat 70-71, al-Hujurat ayat 6, Hud ayat 36, Yusuf ayat 113, Ali Imron ayat 134 dan 161, an-Nisa 58 dan Surat al-'Araf ayat 56.38

${ }^{34}$ Abidin Ibnu Rusn, Pemikiran Al-Ghazali Tentang Pendidikan, Pustaka Pelajar, Yogyakarta, 1998, hlm. 30.

35 Al-Ghazali, Ringkasan Ibya’ Ulumuddin, Gita Media Press, Surabaya, 2003, hlm. 183.

${ }^{36}$ Rus'an, Intisari Filsafat Imam Al-Ghazali, Bulan Bintang, Jakarta, 1989, hlm. 5.

${ }^{37}$ QS an-Nisa ayat 125 artinya: "Dan siapakah yang lebih baik agamanya daripada orang yang dengan ikhlas tunduk kepada Allah, sedang dia mengerjakan kebaikan dan mengikuti agama Ibrahim yang lurus Dan Allah mengambil Ibrahim menjadi kesayangan-Nya". QS Fush Shilat ayat 33 artinya: "Siapakah yang lebih baik perkataannya, daripada orang yang menyeru kepada Allah, mengerjakan amal yang shaleh, dan berkata: 'Sesungguhnya aku termasuk orang-orang yang berserah diri'.

38 Abdurezak A. Hashi, "Islamic Ethics: An Outline of Its Principles and Scope", Revelation and Science Journal, Vol. 01 No. 03, 2011, hlm. 124-125. 
Dari petunjuk di atas, mengisyaratkan bahwa akhlak al-karimah merupakan sebuah konsep yang ilahi, transendental, universal dan pedoman hidup. Hal ini disebabkan beberapa hal, pertama bahwa penentuan baik atau buruk, layak atau tidaknya suatu tindakan manusia hanyalah terletak pada Allah yang menentukannya. Kedua, pada hakikatnya manusia adalah fitrah, oleh karenanya manusi berkecenderungan untuk berbuat baik sesuai tuntunan Allah. Ketiga, ajaran Islam mengandung nilai keadilan dan kesetaraan di mana kedua hal ini berlaku universal. Keempat, tindakan manusia diukur berdasarkan niatnya yang sesuai dengan perintah Allah. Kelima, akhlak tidak hanya berlaku pada orang banyak atau minoritas. Akhlak harus membawa kebermanfaatan bagi semua golongan orang. Tidak ada pembedaan atara mayoritas dan minoritas. Keenam, akhlak selalu berorintasi pada kemaslahatan dan mengantisipasi kemudharatan bagi manusia. ${ }^{39}$

\section{Rujukan Bisnis Islam}

Sama seperti halnya dalam aktifitas lainnya, setiap muslim yang menjalankan bisnis juga merujuk kepada Al-Qur'an dan Hadits. Bahkan ada pendapat yang mengatakan bahwa rujukan setiap aktifitas umat muslim yang berkonsekuensi pada pengaturan hukum tidak hanya sebatas Al-Qur'an dan Sunnah saja, tetapi juga meliputi ijma', qiyas, istihsan, istishab, sad al-dzari'ah, 'Urf, syar'man qablana, dan mazhhab al-shahabi. Namun, yang dinisbatkan sebagai sumber utama dan paling utama adalah Al-qur'an dan Sunnah. ${ }^{40}$

\section{Al-Qur'an}

Setidaknya terdapat tujuh istilah yang terkandung dalam Al-Quran tentang bisnis. Namun hanya empat kata yang paling lazim dan umum memiliki kedekatan makna dengan bisnis, yaitu tijarah (perdagangan), bay' (menjual) dan Syira' (membeli). Selain istilah tersebut masih banyak lagi term lain yang berkaitan dengan bisnis, seperti dayn, amwal, rizq, syirkah, dharb, dan sejumlah perintah melakukan perdagangan global. ${ }^{41}$ Kata tijarah ini disebut sebanyak 8 kali dalam Al-

${ }^{39}$ Ibid., hlm. 126-127.

${ }^{40}$ Fathurrahman Djamil, Hukum Ekonomi Islam; Sejarah, Teori dan Konsep, Sinar Grafika, Jakarta, 2013, hlm. 73.

${ }^{41}$ Lihat Qur'an Surat Al-Jumu'ah ayat 9 yang artinya: "Hai orang-orang yang beriman, apabila diserukan untuk menunaikan shalat pada hari Jum'at, maka bersegeralah kamu kepada mengingat Allah, dan tinggalkanlah jual-beli. Yang demikian itu lebih baik bagimu, jika kamu mengetahui”. 
Quran yang tersebar dalam tujuh surat. ${ }^{42}$ Sedangkan kata bai' disebut sebanyak 4 kali dalam Al-Quran. ${ }^{43}$ Selanjutnya kata lainnya yang juga dipergunakan Al-Quran adalah As-Syira. Kata ini terdapat dalam 25 ayat. Dua ayat di antaranya berkonotasi perdagangan dalam konteks bisnis yang sebenarnya, yaitu yang kisah Al-Quran yang menjelaskan tentang Nabi Yusuf yang dijual oleh orang menemukannya yang terdapat dalam Qur'an Surat Yusuf ayat 21 dan $22 .{ }^{44}$

Dari uraian di atas dapat dipahami bahwa penggunaan kata tertentu yang menunjukkan makna bisnis menggambarkan bahwa praktik bisnis merupakah hal penting sehingga penyebutannya secara langsung dan jelas. Selain itu juga AlQur'an mengatur sedemikian rupa praktik bisnis ini. Sebagai contoh dalam Qur'an Surat Al-Maidah ayat 1 mewajibkan orang-orang yang beriman untuk mematuhi perjanjian yang mereka buat. ${ }^{45}$ Perintah tersebut menjadi dasar pengaturan perjanjian bisnis jual beli. Selain itu juga diatur mengenai takaran yang tidak merugikan, timbangan yang lurus dan tidak melampaui batas dan perintah menegakkan timbangan secara adil tanpa kecurangan. ${ }^{46}$

\section{Sunnah}

Sunnah dipahami sebagai ajaran Rasulullah Muhammad SAW yang berupa ucapannya, tindakannya atau persetujuannya. Ajaran tersebut kemudian diwartakan perekamannya melalui proses yang dapat dipertanggungjawabkan yang disebut dengan hadist. ${ }^{47}$ Dalam konteks bisnis, terdapat cukup bukti yang mendukung eksistensi praktik bisnis yang dilakukan oleh Muhammad baik

${ }^{42}$ Ketutuh surat tersebut yaitu Al-Baqarah: 16 dan 282, An-Nisa': 29, at-Taubah: 24, An-Nur:37, Fathir: 29 , Shaf: 10 dan Al-Jum'ah:11. Pada Qur'an Surat Al-Baqarah disebut dua kali, sedangkan pada Surat lainnya hanya disebut masing-masing satu kali. Lihat Achmad Lutfi, "Penafsiran Ayat-Ayat Ekonomi Dalam Al-Qur'an (Mengungkap Makna Bai' dan Tijarah Dalam Al-Qur'an)”, Jurnal Holistik, Vol. 12 No 12, 2011, hlm. 76.

43 1) Qur'an Surat Al-Baqarah ayat 254, 2) Qur'an Surat Al-Baqarah ayat 275, 3) Qur'an Surat Ibrahim ayat 31 dan 4) Qur'an Surat Al-Jum'ah ayat 9

${ }_{44}$ Anonim, "Perdagangan Dalam Al-Qur'an" dalam http://zonaekis.com/perdagangan-dalam-al-quran/ diakses pada tanggal 13 Juli 2016

${ }^{45}$ Qur'an Surat Al-Maidah ayat 1 yang artinya: "Hai orang-orang yang beriman, penuhilah aqad-aqad itu..."

46 Lihat Qur'an Surat Asy-Syu'araa' ayat 181-182 yang artinya: “Sempurnakanlah takaran dan janganlah kamu termasuk orang-orang yang merugikan dan timbanglah dengan timbangan yang lurus". Lihat juga Qur'an Surat ayat Ar-Rahman ayat 8-9 yang artinya: "Supaya kamu jangan melampaui batas, tentang neraca itu. Dan tegakkanlah timbangan dengan adil, dan janganlah kamu mengurangi neraca itu”. Lihat Ridwan Khairandy, Perjanjian Jual Beli, FH UII Press, Yogyakarta, hlm. 2016, hlm. 16-17.

${ }^{47}$ Ibid 
sebelum dan setelah kenabiannya. Setidaknya terdapat tiga bentuk praktik bisnis yang diterapkan oleh Rasulullah Muhammad SAW, yaitu:48

Pertama, transaksi penjualan, sebagaimana hadist yang diriwayatkan oleh Tirmidzi, Abu Dawud dan Ibn Majah yang menerangkan Anas meriwayatkan bahwa Nabi pernah menawarkan sebuah kain pelana dan bejana untuk minum seraya mengatakan: "Siapa yang ingin membeli kain pelana dan bejana air minum?" Seorang laki-laki menawarnya seharga satu dirham, dan Nabi menanyakan apakah ada orang yang akan membayar yang lebih mahal. Seorang laki-laki menawar padanya dengan harga dua dirham, dan Nabi pun menjual barang tersebut padanya.

Kedua, transaksi pembelian, sebagaimana hadist yang diriwayatkan oleh Bukhari dan Muslim bahwa Muhammad melakukan transaksi pembelian dalam jumlah yang besar terutama pada masa sebelum kenabiannya. Jabir berkata, "Saya sedang melakukan perjalanan dengan menunggang seekor unta yang sudah kelelahan, tetapi ketika Nabi lewat dan memukulnya, unta tadi berjalan lagi. Ini belum pernah ia lakukan sebelumnya. Nabi SAW lalu berkata: “Juallah unta itu padaku seharga satu uqiyah (40 dirham). Saya setuju, tetapi dengan syarat boleh mengendarainya sampai ke rumah. Ketika sampai di Madinah, saya serahkan unta tersebut dan ia membayar kontan."

Ketiga, pembelian berdasarkan kredit, sebagaimana hadist yang diriwayatkan Muslim bahwa Abu Rafi” berkata, “Nabi telah meminjam seekor unta yang masih muda, dan ketika unta-unta sedekah datang padanya, ia menyuruh saya untuk membayar orang yang menjual unta yang masih muda itu. Ketika saya katakan padanya bahwa saya hanya mampu mendapatkan seekor unta bagus yang umurnya tujuh tahun, lalu beliau mengatakan, "berikan padanya unta tersebut, sebab orang yang paling utama adalah yang menebus utangnya dengan cara yang paling baik."

Rasulullah Muhammad SAW pernah mengatakan bahwa sebagian besar rezeki manusia bersumber dari aktifitas bisnis. Hadist yang diriwayatkan oleh Ibrahim Al-Harabi menyebutkan yang artinya berdaganglah kamu, sebab lebih

${ }^{48}$ Muhammad, Etika Bisnis Islami, UPP AMP YKPN, Yogyakarta, 2004, hlm. xvi. 
dari sepuluh bagian penghidupan, sembilan di antaranya dihasilkan dari berdagang. Oleh sebab itu, diperlukan bisnis yang bermoral. Rasulullah telah banyak memberi contoh tentang sistem berbisnis yang bermoral, yaitu berbisnis dengan jujur dan adil serta tidak merugikan pihak manapun. Sebagaimana Rasul bersabda yang diriwayatkan oleh Abu Sa'id menegaskan: "Saudagar yang jujur dan dapat dipercaya akan dimasukkan dalam golongan para nabi, golonga orangorang jujur, dan golongan para syuhada. ${ }^{49}$

Berdasarkan uraian hadist di atas nampak bahwa Rasulullah SAW telah mengajarkan untuk bertindak jujur dan adil serta bersikap baik dalam melakukan bisnis. Selain itu, Rasulullah juga mengajarkan kunci kesuksesan bisnis dengan menerapkan sifat-sifat terpuji beliau yang dikenal penduduk Makkah saat itu adalah jujur (Shiddiq), menyampaikan (tabligh), dapat dipercaya (amanah), dan cerdas dan bijaksana (fathanah). ${ }^{50}$ Dari hal ini tentunya sifat kenabian tersebut layak dan sepatutnya menjadi rujukan bagi umat muslim dalam melakukan praktik bisnis.

\section{Prinsip dasar ajaran Islam yang relevan dengan praktik bisnis}

Secara bahasa, bisnis dapat diartikan sebagai usaha, perdagangan, toko, perusahaan, tugas, urusan, hak, usaha dagang, usaha komersial dalam dunia perdagangan atau bidang usaha. Dari arti bahasa tersebut, bisnis dapat dipahami sebagai aktifitas riil ekonomi yang secara sederhana dilakukan dengan cara jual beli atau pertukaran barang dan jasa. Sedangkan dari pengertian secara terminologis, bisnis dipahami sebagai aktifitas atau kegiatan usaha yang terorganisir untuk menghasilkan atau menjual barang dan jasa guna mendapatkan keuntangan dalam memenuhi kebutuhan masyarakat. ${ }^{51}$

Agar keuntungan yang ingin diraih dapat menambah kebaikan baik bagi pelaku bisnis itu sendiri atau pun lingkungan sekitarnya, maka praktik bisnis mesti mengacu prinsip-prinsip dasar yang mencerminkan nilai-nilai luhur yang universal. Setidaknya terdapat lima prinsip dasar sebagai berikut:52 Pertama, prinsip

\footnotetext{
49 Jusmaliani, dkk, Bisnis Berbasis Syariah, Bumi Aksara, Jakarta, 2008, hlm. 46.

${ }^{50}$ Ibid

${ }^{51}$ R. Lukman Fauroni, Op. Cit., hlm. 26.

52 Hendri Hermawan Adinugraha, "Norma dan Nilai Dalam Ilmu Ekonomi Islam”, Jurnal Media Ekonomi \& Teknologi Informasi, Vol. 21 No. 1, 2013, hlm 53-56.
} 
tauhid. Sebagaimana yang telah dijelaskan, bahwa tauhid atau akidah merupakan fondasi fundamental ajaran Islam. Pada intinya bahwa prinsip ini menegaskan bahwa Allah adalah pemilik sejati seluruh yang ada di alam semesta ini. Allah tidak menciptakan sesuatu dengan sia-sia dan manusia diciptikan hanya untuk beribadah kepada-Nya. Oleh karena itu, pelaksanaan bisnis seharusnya didasarkan pada konsep penyerahan diri dan menyakini bahwa semua yang diperjual belikan dalam bisnis hanyalah milik Allah semata, melaksanakan bisnis berbasis ibadah.

Kedua, prinsip keadilan. Allah adalah Sang pencipta seluruh yang ada di muka bumi ini, dan 'adl (keadilan) merupakan salah satu sifat-Nya. Allah menganggap semua manusia itu sama (egalitarianism) di hadapan-Nya dan memiliki potensi yang sama untuk berbuat baik, karena yang menjadi pembeda bagi-Nya hanya tingkat ketaqwaan setiap individunya. Prinsip ini mengajarkan manusia agar dapat berlaku adil dalam segala hal, terutama dalam kontek bisnis.

Ketiga, prinsip Nubuwwah (Kenabian). Prinsip ini menegaskan bahwa Nabi Muhammad merupakan model yang ideal dalam segala perilaku, termasuk juga perilaku bisnis yang seyogyanya dapat diteladani serta diimplementasikan oleh setiap manusia, khususnya para pelaku bisnis. Sehingga tidak heran jika ia memiliki 4 (empat) sifat yang sering dijadikan landasan dalam aktivitas manusia sehari-hari termasuk juga dalam aktivitas bisnis karena selain bidang leadership ia juga sangat perpengalaman dalam bidang perdagangan. Empat sifat tersebut adalah: (1) Shiddiq (benar, jujur, valid). Sifat shiddiq ini akan muncul konsep efektivitas dan efisiensi. Efektivitas dimaksudkan untuk mencapai tujuan yang tepat (on time) dan benar (all right), sedangkan efisiensi adalah melakukan aktivitas dengan benar dan hemat, maksudnya menggunakan teknik dan metode yang tidak menyebabkan kemubadziran; (2) Amanah (responsibility, dapat dipercaya, kredibilitas). Sifat ini dapat membentuk pribadi yang kredibel dan memiliki sikap penuh tanggung jawab. Sifat amanah memiliki posisi yang fundamental dalam aktivitas bisnis, karena tanpa kredibilitas dan tanggung jawab dalam berperilaku, maka kehidupan bisnis menjadi tidak stabil. (3) Fathanah (kecerdasan, kebijaksanaan, profesionalitas, intelektualitas). Implikasi sifat ini dalam aktivitas bisnis adalah bahwa segala aktivitas harus dilakukan dengan ilmu atau kecerdasan, dan optimalisasi semua potensi akal (al-'aqlu) yang ada untuk 
mencapai tujuan (goal). Memiliki kredibilitas dan responsibility yang tinggi saja belum cukup dalam menjalankan kehidupan berbisnis. Tetapi apabila dilengkapi dengan akal cerdas dan sikap profesionalitas yang mumpuni maka hal ini akan lebih mudah dalam menjalankannya (konsep "work hard and smart"); (4) Tabligh (komunikatif, transparansi, marketeble). Sifat tabligh dalam bisnis menurunkan prinsip-prinsip ilmu komunikasi (personal, interpersonal), seperti penjualan, pemasaran, periklanan, pembentukan opini masa, dan lain sebagainya yang dilakukan dengan benar dan proporsional.

Keempat, prinsip khilafah merupakan representasi bahwa manusia adalah pemimpin (khalifah) di dunia ini dengan dianugerahi seperangkat potensi mental dan spiritual oleh Allah SWT, serta disediakan kelengkapan sumber daya alam atau materi yang dapat dimanfaatkan dalam rangka untuk sustainibilitas atau keberlangsungan hidupnya. Fungsi utamanya adalah untuk menjaga keteraturan interaksi (mu'amalah) antar pelaku bisnis, agar dapat meminimalisir kekacauan, persengketaan, dan keributan dalam aktivitas mereka.

Kelima, prinsip ma'ad (hasil). Prinsip ini mengajarkan bahwa pada dasarnya manusia diciptakan di dunia ini untuk berjuang dan bekerja. Dalam perspektif Islam, dunia adalah ladang akhirat, maksudnya dunia merupakan tempat bagi manusia untuk mencari bekal dengan bekerja, beraktivitas, dan beramal baik. Pada prinsipnya perbuatan baik akan dibalas dengan kebaikan, dan demikian juga sebaliknya. Oleh karena itu, ma'ad bermakna balasan, imbalan, ganjaran. Menurut Imam Al-Gazhali implikasi konsep ma'ad dalam kehidupan bisnis misalnya, mendapatkan profit/laba sebagai motivasi para pelaku bisnis. Laba tersebut bisa didapatkan di dunia dan bisa juga kelak akan diterima di akhirat. Karena itu konsep profit/laba mendapatkan legitimasi dalam Islam.

Pendapat lain mengutarakan bahwa prinsip dasar yang harus diadopsi oleh pelaku bisnis dalam perspektif Islam adalah bahwa praktik bisnis tersebut harus mencerminkan karakter yang mengandung nilai-nilai rohaniah bahwa segala sesuatu hanyalah ciptaan Allah; memiliki pemahaman bisnis yang halal dan haram; dan berorientasi pada hasil dunia dan akhirat. ${ }^{53}$ Selain itu, bisnis yang

53 Mardani, Hukum Bisnis Syariah, Prenadamedia Group, Jakarta, 2014, hlm. 23-24. 
dijalankan harus menghindarkan praktik pemberian hadiah atau komisi dalam lobi bisnis; tidak makan riba; tidak wanprestasi; tidak suap; tidak menipu; tidak zalim dan input, proses serta output harus bebas dari barang dan jasa yang haram. ${ }^{54}$

Pendapat yang hampir serupa juga mengulas bahwa setidaknya terdapat lima prinsip yang harus melandasi suatu bisnis. Prinsip pertama adalah Kesatuan (Unity), prinsip ini menyuguhkan keterpatuan agama, bisnis dan sosial demi membentuk kesatuan. Atas dasar itu, maka praktik bisnis harus dijalankan tanpa mengesampingkan kemasan nilai-nilai religious. Prinsip kedua adalah keseimbangan (equilibrium), prinsip ini pada hakekatnya sama dengan prinsip keadilan yang telah dijelaskan di atas. Prinsip ketiga adalah kehendak bebas, prinsip ini mengajarkan bahwa manusia diciptakan dengan memiliki kehendak bebas untuk menentukan arah kehidupannya. Dalam konteks bisnis, manusia bebas menentukan perjanjian yang dibuatnya, termasuk menepati ataupun mengingkarinya. Setiap muslim yang percaya pada kehendak Allah, maka akan memuliakan janji yang telah dibuatnya. Dengan demikian prinsip ini berhubungan erat dengan prinsip kesatuan dan keseimbangan. Prinsip keempat adalah pertanggungjawaban, prinsip ini menetapkan bahwa manusia memiliki kebebasan, namun kebebasan tersebut terbatas oleh tanggung jawab atas apa yang dilakukannya. Dalam konteks bisnis, pelaku bisnis bertanggung jawab tidak hanya untuk mencari keuntungan namun juga memperbaiki kualitas lingkungan sosial dan tidak menimbulkan kerugian bagi konsumen. Prinsip kelima adalah kebenaran, kebajikan dan kejujuran, prinsip ini merupakan buah dari akhlak karimah. Setiap kebajikan diyakini sebagai tindakan yang tidak merugikan orang lain dan kejujuran juga cerminan dari salah satu sifat nubuwwah dalam penjelasan prinsip di atas. ${ }^{5}$

\section{Penutup}

Berdasarkan pandangan Islam, prinsip-prinsip dasar praktik bisnis yang harus dijadikan landasan bersumber pada Al-Qur'an dan Sunnah. Bangunan prinsip tersebut harus dibingkai dalam kerangka dasar ajaran Islam, yaitu Akidah, Ibadah dan Akhlak. Dari kerangka tersebut tercipta prinsip dasar praktik bisnis

\footnotetext{
${ }^{54}$ Ibid., hlm. 25.

${ }^{55}$ R. Lukman Fauroni, Op. Cit., hlm. 144-164
} 
sebagai berikut: prinsip tauhid dan kesatuan (unity), prinsip nubuwwah dan kebenaran (kebijakan dan kejujuran), prinsip khilafah dan pertanggungjawaban, dan prinsip keadilan dan keseimbangan. Nilai-nilai moral yang terkandung dalam prinsip-prinsip tersebut di atas bersifat universal dan dapat berlaku dalam keadaan dan waktu kapanpun. Nilai-nilai tersebut adalah nilai keadilan, kejujuran, amanah, profesional, transparan, dapat dipercaya, jauh dari hal yang haram dan kezaliman.

Penerapan prinsip dan nilai-nilai di atas menjamin praktik bisnis apapun tidak hanya sebatas di bidang makanan akan terhindar dari kemudhoratan, dijauhkan dari tindakan merugikan dan membahayakan konsumen. Jaminan ini jelas datang langsung dari Allah melalui kalamNya.

\section{Daftar Pustaka}

\section{Buku}

Abdullah, M. Yatimin, Studi Akhlaq dalam Perspektif Al-Qur'an, Amzah, Jakarta, 2007.

Ahmad, Mustaq, Etika Bisnis Dalam Islam, Pustaka Al-Kautsar, Jakarta, 2001.

Ahmad Ibn Faris ibn Zakariya, Abu Husain, t.th, Mu'jam Maqa yis al-Lugah, Juz IV, Daar al-Fikr, Beirut.

Alim, Muhammad, Pendidikan Agama Islam, PT. Remaja Rosdakarya, Bandung, 2006.

Al-Ghazali, Ringkasan Ihya' Ulumuddin, Gita Media Press, Surabaya, 2003.

al-Maududi, Abul A'la, Prinsip-prinsip Islam, Cet. Ke-2, Penterjemah, Abdullah Suhaili, PT Alma'arif, Bandung, 1983.

Al-Munawar, Said Agil Husin, Aktualisasi Nilai-Nilai Qur'ani Dalam Sistem Pendidikan Islam, Ciputat Press, Jakarta, 2003.

Al-Qur'an Al Karim

Ash Shiddieqy, Hasbi, Sejarah dan Pengantar Ilmu Tauhid/Kalam, Bulan Bintang, Jakarta, 1973. , Ilmu Kalam, Bulan Bintang, Jakarta, 1986.

Buchari, Alma, Manajemen Pemasaran dan Pemasaran Jasa, Cet. Ke-8, Alfabeta, Bandung, 2009.

Djamil, Fathurrahman, Hukum Ekonomi Islam; Sejarah, Teori dan Konsep, Sinar Grafika, Jakarta, 2013.

Fauroni, R. Lukman, Etika Bisnis Dalam Al-Qur'an, Pustaka Pesantren, Yogyakarta, 2006.

Ismail, Ghoffar, dkk., Panduan Kuliah Intensif al-Islam (KIAI) UMY, Edisi Revisi, LPPI UMY dan UNIRES Pres, Yogyakarta, 2014.

Jusmaliani, dkk., Bisnis Berbasis Syariah, Bumi Aksara, Jakarta, 2008.

Khairandy, Ridwan, Perjanjian Jual Beli, FH UII Press, Yogyakarta, 2016. 
Mardani, Hukum Bisnis Syariah, Prenadamedia Group, Jakarta, 2014.

Ma'luf, Louis, Al Munjid, Dar al Masyrid, Beirut, 1997.

Muhammad, Etika Bisnis Islami, UPP AMP YKPN, Yogyakarta, 2004.

Muhammad bin Kasir, Abu al-Fida, t.th, Tafsir al-Qur'an al-Karim, Juz I, Toha Putra, Semarang.

Razak, Nasiruddin, Dienul Islam, PT al-Ma'arif, Bandung, 1971.

Rusn, Abidin Ibnu, Pemikiran Al-Ghazali Tentang Pendidikan, Pustaka Pelajar, Yogyakarta, 1998.

Rus'an, Intisari Filsafat Imam Al-Ghazali, Bulan Bintang, Jakarta, 1989.

Shihab, M. Quraish, Fatwa-fatwa Seputar Ibadah Mahdah, Cet. I, Mizan, Bandung, 1999.

Syukur, Amin, Pengantar Studi Islam, CV Bima Sakti, Semarang, 2003.

Tim DPPAI, Pilar Substansial Islam, Cetakan Ketiga, DPPAI UII, Yogyakarta, 2016.

Tono, Sidik, dkk., Ibadah dan Akhlak dalam Islam, Cet. Ke-3, UII Press, Yogyakarta, 2009.

\section{Jurnal}

Adibah Binti Abdul Rahim, "Understanding Islamic Ethics and Its Significance on the Character Building", International Journal of Social Science and Humanity, Vol. 3 No. 6, 2013.

Adinugraha, Hendri Hermawan, "Norma dan Nilai Dalam Ilmu Ekonomi Islam", Jurnal Media Ekonomi \& Teknologi Informasi, Vol. 21 No. 1, 2013.

Amalia, Fitri, "Etika Bisnis Islam: Konsep Dan Implementasi Pada Pelaku Usaha Kecil", Al-Iqtishad, Vol. VI No. 1, 2014.

Hashi, Abdurezak A., "Islamic Ethics: An Outline of Its Principles and Scope", Revelation and Science Journal, Vol. 01 No. 03, 2011.

Lutfi, Achmad, "Penafsiran Ayat-ayat Ekonomi Dalam Al-Qur'an (Mengungkap Makna Bai' dan Tijarah Dalam Al-Qur'an)", Jurnal Holistik, Vol. 12 No 12, 2011.

\section{Internet}

Anonim, "Digerebek, Pabrik Saus di Bandung Ini Pakai Pewarna Tekstil Bukan Cabai dan Tomat" dalam https://news.detik.com/jawabarat/2814332/digerebek-pabrik-sausdi-bandung-ini-pakai-pewarna-tekstil-bukan-cabai-dan-tomat, diakses pada tanggal 10 Juni 2016.

http://food.detik.com/read/2012/08/01/154109/1980557/297/waspadai-nata-de-cocomengandung-pemutih-dan-boraks, diakses pada tanggal 12 Juli 2016.

Fadhil Al Birra, "Waspada! Ikan Berformalin Banyak Beredar, Begini Cara Membedakannya" dalam https://www.jawapos.com/read/2017/06/09/136193/ waspada-ikan-berformalin-banyak-beredar-begini-cara-membedakannya, diakses pada tanggal 10 Juni 2017.

http://zonaekis.com/perdagangan-dalam-al-quran/ diakses pada tanggal 13 Juli 2016 